\title{
Supervision for School Career Counsellors: Supervisors' Opinion
}

\author{
Rita Burceva Mg.paed., Mg. hrm. \\ Rezekne Academy of Technologies, Latvia \\ rita.burceva@rta.lv
}

\begin{abstract}
Supervision is a relatively new form of support for employees in Latvia, and there are still no put in practice ideas on their positive role in strengthening the potential of human resources. Topicality and problem of this research is following there is a lack of knowledge and experience in the provision of supervision for providers of career support, therefore it is difficult to take an advantage of this important development and support tool for the professional development of employees. The objective of research - to study the role of supervision as a development and support tool for the professional development and support of - school career counsellors within the framework of the ESF project "Career Development Support at General and Vocational Schools", gathering information on the views of supervisors of the carried-out supervisions. Research methods: theoretical literature analysis, primary data collection (interviews with supervisors). In the supervisors' view the most important benefits for school career counsellors are the following: confirmation of the direction taken by school career counsellors, recognising their strengths and weaknesses, making new contacts, support from and communication with colleagues, dealing with similar problem situations, new ideas and information, planning of work skills, active sharing of experiences, gathered information on the specific professional activity of school career counsellors in relation to the provision of the project's activities. A significant role in the professional development of school career counsellors is played by the ability to reflect and to perceive this process as a necessary ingredient for self-development, therefore the State Education Development Agency must position supervision publicly as an efficient tool for the professional development and support of school career counsellors, and as a concept for the promotion of improvement of professional competence of school career counsellors in a short span of time through skilful, timely and systematic use of this tool. As a result of the research a proposal was formulated to recommend revising the professional standard of career counsellor, establishing the requirement of supervision as a development and support tool for the perfection of competence and quality of professional activity.
\end{abstract}

Keywords: school career counsellor, supervision, supervisors' opinion, school education.

\section{Introduction}

In the dynamic work environment of today new requirements are set out for employees - not only they must be able to tackle the urgent assignments in the present, but they should also be able to see a wider context and project acceptable solutions in situations which are yet to develop in the future. In addition to the provision of education in its classic sense, we are constantly in search of new support and training tools for employees allowing them to keep pace with the development trends in the sector, to broaden their experience, to receive support in complex situations of their professional activity. Such tools are mentoring, coaching, master classes, professional conferences, business games, training in various fields, webinars, internet resources (recordings of interviews, e-books), supervisions. Their purpose is to broaden the understanding of employees on the variety of available resources at their disposal to carry out their work assignments, to demonstrate and to allow them to test the most efficient methods in tackling complex situations, to make the professional experience of other sectors more accessible, to reduce their stress levels and the risks for burnout, to stabilise team relationships and to unite members of the teams for joint projects, to facilitate to the understanding of the goal and the change of action, to develop their planning skills, to adjust behaviour.

In 2016 the State Education Development Agency (SEDA) started implementing the project "Career Development Support at General and Vocational Schools" funded by the European Social Fund (ESF). In the local authorities with active collaboration agreements with the SEDA, there are schools and Vocational Education Competence Centres (VECC) that employ school career counsellors. They are ready to work, however the required supervision in this profession is still inadequate. There is also a lack of support mechanisms, which would allow taking new challenges more boldly, learning to get satisfaction from their work and to assess their success, facilitating to their professional development. 
Being fully aware of these risk factors, supervision is one of the planned activities in the area of support and professional development for school career counsellors within the framework of the ESF project "Career Development Support at General and Vocational Schools". Supervision is a relatively new form of support for employees in Latvia, and there are still no put in practice ideas on it's positive role in strengthening the potential of human resources. Although it works efficiently in the sphere of business and it is also used in some care professions (social pedagogue, psychologist, medical practitioner), nevertheless employers in the education sector not only lack the understanding of educational nature and role of supervision for the professional development of their employees and the development of human resources, the specifics of the process, as there is a very limited practical experience in this field, but they also don't appreciate its significance in terms of the provision of overall quality of work for school career counsellors in the field. The set of circumstances highlight the topicality and problem of this research - there is a lack of knowledge and experience in the provision of supervision for providers of career support, therefore it is difficult to take an advantage of this important development and support tool for the professional development of employees. For the purpose of the project, they are school career counsellors, for whom the educational and support function of supervision plays an important role in their professional development.

The author's personal interest in the study of this project is determined by her previous experience in the development of the professional standard for career counsellors and involvement in the implementation of activities of the ESF project "Career Development Support at General and Vocational Schools" now.

The aim of research - to study the role of supervision as a development and support tool for the professional development and support of school career counsellors within the framework of the ESF project "Career Development Support at General and Vocational Schools", gathering information on the views of supervisors of the carried-out supervisions.

\section{Methodology}

The tasks of research:

1) Analysing the scientific literature on the theoretical aspects of professional development and supervision as a form of support and educating,

2) Conducting a qualitative research (interviews with supervisors), establishing the view of respondents on the present professional and personal benefits of the supervision experience, the acquired problem-solving techniques, attitude towards supervision, the future aspirations in terms of supervision for the purpose of professional development.

The questions of research:

1) What are the most important professional and personal eventual benefits of school career counsellors in the context of development and support in the supervision process?

2) To what extent school career counsellors are satisfied with their supervision?

3) What are the differences in terms of professional and personal benefits and satisfaction with supervision between school career counsellors of comprehensive schools and those of the VECCs?

4) What topics should we cover by future supervisions for school career counsellors in order to promote the development of employees in the sector and to ensure the necessary support?

Research methods:

1) Theoretical literature analysis,

2) Primary data collection methods (interviews with supervisors).

The empirical research was conducted during the period between October 2018 and October 2019, when supervisions for school career counsellors were held. In the research four supervisors, who conducted supervisions for school career counsellors within the framework of the ESF project "Career Development Support at General and Vocational Schools", were interviewed. The interviewed supervisors conducted 2-24 supervisions for school career counsellors. The aim of these interviews was to collect the supervisors' opinions on the importance of the conducted supervisions for the development and support of school career counsellors. A semi-structured interview was used as this format allows including details, which would have been left unaddressed during the process of structured interviews. 


\section{Results and Discussion}

Supervision is an interaction between two or more persons, where relationships and their manifestation develop in a harmonious way and this format allows participants to "open up" and to cooperate in a supporting way for the purpose of providing and receiving feedback on what they have experienced, heard, observed and understood. Upon the analysis of processes within a supervision group, B. Proctor notes the importance of the provision of an individual environment for reflection to each participant for successful feedback (Proctor, 2000), understanding it as supportive attitude, mutual acceptance, willingness to immerse themselves into it to establish the true nature of events or emotional experience. The pace of an individual participant of the supervision should not come into dissonance with the common pace of the group, the key principles of supervision and the ability to fit in the group's structure of development. This concept is further developed by L. Āboltina, who asserts that respecting and developing an environment for reflection is a priority in the context of development and training needs of supervision participants and random presenters (Āboltina, 2012). Each participant reflects about an event seeking its meaning. Any information affects a person's behaviour to the extent he has revealed his personal meaning (Dharmadasa, 1994).

Reflection activity skills not only form the basis for the analysis of one's personal experience, but also for critical thinking skills. During the process of reflection an individual is able to adjust his views, attitude, behaviour and plan his further activities much more successfully, taking into account the newly acquired findings as a result of processing a complex situation. L. Ërgle and L. Rutka declares the teachers need regular and deep support, which would offer a transformative learning environment characterised by reflection and self-evaluation (Ërgle, Rutka, 2016). Supervision takes place in an inclusive dialogue format. The benefits, the philosophical, social and ethical aspects of dialogue are described in a number of authors' studies (Anderson, Cissna, Arnett, 1994; Brockbank, McGill, 2006; Soika, 2017). These aspects are important in the supervisor's work. The ability to reflect is also important in communication with difficult clients, when it is required to provide a complicated explanation according to the level of their perception.

Empathy is one of the highest valued personal characteristics of a school career counsellor, because not only it allows performing the algorithmically correct actions in the process of counselling a client, but it also allows them getting to the root of the problem, thus coming up with the most suitable individual solution for a particular person. Owing to the sense of empathy, people can resonate with other or another person's wellbeing at various levels, and we expect pieces of advice and support from these people because they are usually more responsive, caring and noble human beings. For all that, working systematically in the mode of constantly making themselves familiar with other person's problems, the psychological resources of an empathetic person can run low and the burning out may commence. It becomes difficult for them to manage their own emotions, quick tiredness and the feeling of being low are observed, because they also have to listen to negative experiences of their clients or they suffer from what they have experienced themselves, such as through the interaction with less responsible colleagues or persons outside their team, they may start to feel being taken advantage of and undervalued, and it creates preconditions for depression. Suffering of the loss of strength, they cannot help other people because they need to get their priorities right in the first hand before they can start tackling problems of other people. Supervision is a suitable tool for the prevention of risks of professional burnout. Through the reflection on their activity, school career counsellors are given an opportunity to receive encouragements and support from a supervisor and colleagues.

There is a number of theoretical researches for supervisor work outlining that a triad of functions within professional supervision is commonly recognized (Hawkins, Shohet, 2012; Inskipp, Proctor, 1988; Kadushin, 1976). It is notable, that with regard to supervisor's essential role in communicating both upwards and downwards in an organization, mediation as a fourth function is added to the three core elements, namely management, development and support (Morrison, 2005). It needs to be pointed out that the language describing these functions also varies in literature pertaining to supervision, on one hand, reflecting professional cultures but on the other hand, adapting to changing expectations (Patterson, 2019), as for instance, P. Hawkins and R. Shohet have intentionally dealt with developmental, resourcing and qualitative functions to point out shared responsibility between supervisor and supervisee (Hawkins, Shohet, 2006; Hawkins, Shohet, 2012). In theoretical researches, there are also some formulated ideas on the connection between supervision and a person's self-actualisation, professional identity and autonomy in his professional activity, expanding of creative skills, and the improvement of individual competences in the course of career development. 
Foreign experience reveals that supervision may also function independently as one of the forms of lifelong learning. The efficiency of supervisions continues to improve, because, according to I. StankusViša, the notion of supervision is becoming clearer and supervision is conducted within a certain framework of already established professional standards and quality systems. It must be noted that supervision plays an increasing role in professional development of the work force nowadays, because supervision is practiced along with other forms of professional consulting (Stankus-Viša, 2017).

A. Hodge (2007) indicates in relation to the significance of professional development in the process of supervision that supervision is interpersonal learning in an emotional safe environment, and the common creative activity developing relationships and mutual support. It provides a forum for reflection - the environment promoting emotional and professional wellbeing, which broadens the professional perspective through dialogue and giving and receiving feedback.

The main key functions of supervision - administrative or normative, support or strengthening and educational or formational - are defined by E. Apine, indicating the overall aim to achieve highest possible work quality of a consultant within an organization. With respect to the aforementioned, E. Apine argues that the supervisor impersonates a number of roles, such as the educator, supporter, consultant, colleague, expert, competence specialist, all of which leave an impact on the style of work of a supervisor and his interaction with the supervisee (Apine, 2017).

The needs of its participants, current and required resources are discovered during the process of supervision and the supervisor as a specialist develops and changes at the same time too. However, the supervisor is a process manager, so it is his task to create a free and safe environment for supervision, to make sure that the rules of the working group are observed, to pay attention to the raised problem questions and defined objectives, to choose the most suitable methods in supervision and to provide feedback for all those present. The sense of safety and freedom create such mutual attitudes, which open up broader opportunities for the generation of new solutions, testing of ideas through discussion, it provides suitable microclimate for participants to share their experience, to offer help to one another and to support others. At the end of the supervision the benefits of the session are summarised, changes in thinking are established; successful ideas are clarified, returning to the initial objectives.

As a result of the content analysis of the interviews with supervisors, who conducted supervisions for school career counsellors within the framework of the ESF project "Career Development Support at General and Vocational Schools", the author of the research obtained broader answers to 4 questions raised in this research.

1. What are the most important professional and personal eventual benefits of school career counsellors in the context of development and support in the supervision process?

In the supervisors' view there are the following most important professional benefits for school career counsellors: confirmation of the direction taken by school career counsellors, recognising their strengths and weaknesses, making new contacts, colleague support and communication with them, dealing with similar problem situations, new ideas and information, planning of work skills, active sharing of experiences, gathered information on the specific professional activity of school career counsellors in relation to the provision of the project's activities.

The most important personal benefits of school career counsellors in the course of supervisions: the provided support, recommendations, proposed examples, received feedback, support and encouragement. Created a comfortable and safe environment for conversation, free and unconstrained atmosphere, using humour. Created possibility of communication with less known colleagues, promoted sense of unity and self-esteem, and the understanding that colleagues deal with similar problems.

2. To what extent school career counsellors are satisfied with their supervision?

Supervisors indicate that the attitude and satisfaction of school career counsellors with supervision differ. Those who have been working in the sector professionally for a long period of time are more interested in receiving specific information and clarifying details. Whereas, those who have joined the project recently value every piece of information they can get to help them understand the ways of implementing career counselling at their school. 
The school career counsellors, who are genuinely keen on their work and do it at their own initiative, have a positive attitude towards supervision as a form of development and support. However, there is also a small minority of school career counsellors, who received the certificate of a school career counsellor and joined the project at the school management's request; therefore, their interest in professional development through supervision is lower. The lack of positive attitude towards supervision can also depend on the misunderstanding of the essence and value of this form of development, and the lack of experience.

3. What are the differences in terms of professional and personal benefits and satisfaction with supervision between school career counsellors of comprehensive schools and those of the VECCs?

The answers given by the supervisors provide information, which shows a common trend in the question regarding the differences between the professional and personal benefits and satisfaction with supervision between school career counsellors of comprehensive schools and those of the VECCs.

The differences stem from the condition that students of the VECCs and comprehensive schools have slightly different needs. Whilst the first ones have already taken a decision regarding the direction of their professional career, the second ones must be helped to take this decision. Therefore, school career counsellors select different service providers for the provision career support events; nevertheless, they still use the same work methods in solving different situations. Therefore, it cannot be said that the opinions of school career counsellors employed at comprehensive schools and those of the VECCs on their professional and personal benefits and satisfaction with supervision would differ much. It can be concluded that there are no significant differences in terms of needs and opinions of school career counsellors, and it is not necessary to conduct separate supervisions for these two categories of school career counsellors.

4. What topics should we cover by future supervisions for school career counsellors in order to promote the development of employees in the sector and to ensure the necessary support?

Supervisors were not asked a direct question on the desired topics of supervision, and the methodology of supervision provides for tackling the issues, which are topical to, and chosen by clients themselves. Nevertheless, upon the analysis of interview transcripts several areas emerged, where school career counsellors would appreciate additional support.

One of them is the topic of professional burnout because there are school career counsellors who work at several education establishments at the same time, and it requires excellent managerial skills, organisational talent, the ability to communicate with the managements and teams of teachers of various schools. A large majority of school career counsellors are also teachers of a subject in one or several schools, sometimes even in different counties. Performing various additional duties also follows from the project's requirements to the involved school career counsellors only (it is also confirmed by the analysis of the school career counsellor's job description). Substantial flexibility and the ability to act in uncertain situations are expected from school career counsellors. Under the conditions of increased levels of stress and responsibility, the risk of professional burnout increases, therefore it is necessary to pay more attention to this issue in supervisions.

The insecurity to talk about problem situations at work in front of their colleagues can also be related with the particular person's personal qualities, the lack of leadership skills, inadequate ability to reflect on and analyse situations, a fear of making a mistake, and it can cause even deeper unsolved problems. Participants may experience difficulties in evaluating supervision as an opportunity for gaining and creating new knowledge and transforming attitudes. Participants of supervisions must be encouraged to open up, to share their positive experience more so that each and every one of them can fix their relationship with themselves and colleagues, to receive a needed solution to their question and required support, which is one of the steps for strengthening the professional capacity of school career counsellors.

During supervisions, it is necessary to turn purposefully to the ability of school career counsellors to conceptualise some individual cases of their professional activity in order to learn to see interconnections, to set priorities, to define objectives clearer, to have a better understanding of the philosophy of career counselling. 


\section{Conclusions}

Since it has been established during the research that there is no substantial difference in views of school career counsellors of comprehensive schools and VECCs in terms of professional and personal benefits and satisfaction with supervision, then for the purpose of rational use of resources it is recommended not to organise separate supervisions for the participants of these groups.For the purpose of further development and support of supervision participants it is necessary to address the topics regarding the unanswered questions, e.g. the insecurity of school career counsellors in the provision of individual counselling to pupils, episodic and poor cooperation and the lack of support from school managements, the identification of difficulties and obstacles, the communication related stress, taking new challenges, strengthening the sense of confidence and security.

A significant role in the professional development of school career counsellors is played by the ability to reflect and to perceive this process as a necessary ingredient for self-development, therefore the SEDA must position supervision publicly (in the mass media, in the conferences and seminars of the Latvian Career Development Support Association and other sector professionals, the working groups of other projects) as an efficient tool for the professional development and support of school career counsellors, and as a concept for the promotion of improvement of professional competence of school career counsellors in a short span of time through skilful, timely and systematic use of this tool.

As a result of the research a proposal was formulated to recommend revising the professional standard of career counsellor, establishing the requirement of supervision as a development and support tool for the perfection of competence and quality of professional activity.

\section{Bibliography}

1. Anderson R., Cissna K., Arnett R. C. (Eds.). (1994). The Reach of Dialogue: Confirmation, Voice, and Community. New York: Hampton Press.

2. Apine E. (2017). Supervīzijas process [Process of Supervision]. In K. Mārtinsone, S. Mihailova, Supervīzija: teorija, pētījumi, prakse. Rīga: RSU, 49-65. (in Latvian)

3. Āboltina L. (2012). Reflektīvā darbība sociālo darbinieku supervīzijā [Reflective Activity in the Supervision for Social Workers]. Promocijas darbs. Rīga: LU. Retrieved from https://dspace.lu.lv/dspace/bitstream/handle/7/4663/20124-Liga_Aboltina_2012.pdf (in Latvian)

4. Brockbank A., McGill I. (2006). Facilitating Reflective Learning through Mentoring \& Coaching. London: Kogan Page.

5. Dharmadasa K.H. (1994). Personal Meaning in Learning: Perspectives that Influence the Discovery of Personal Meaning: A Symposium. Paper presented at the Annual Meeting of the Mid-South Educational Research Association. Nashville: TN, November 9-11, 1994. Retrieved from https://files.eric.ed.gov/fulltext/ED390524.pdf

6. Ërgle L., Rutka L. (2016). The Theoretical Nature and Practical Necessity of Pedagogical Supervision. In V. Dislere (Ed.), The Proceedings of the International Scientific Conference Rural Environment. Education. Personality (REEP), 9. Jelgava: LLU, 66-73. Retrieved from https://llufb.llu.lv/conference/REEP/2016/Latvia-Univ-Agricult-REEP-2016proceed2255-808X-66-73.pdf

7. Hawkins P., Shohet R. (2006). Supervision in the helping professions ( $3^{\text {rd }}$ ed.). Maidenhead: Open University Press.

8. Hawkins P., Shohet R. (2012). Supervision in the helping professions (4 ${ }^{\text {th }}$ ed.). Berkshire: Open University Press.

9. Hodge A. (2007). Making the most of our coaching supervision: an appreciative inquiry workshop. Melbourne: ICF.

10. Inskipp F., Proctor B. (1988). Skills for supervising and being supervised. Twickenham: Cascade Publications.

11. Kadushin A. (1976). Supervision in social work. New York: Columbia University Press.

12. Morrison T. (2005). Staff supervision in social care: Making a real difference for staff and service users ( $3^{\text {rd }}$ ed.). Brighton: Pavilion Publishing.

13. Patterson F. (2019). Supervising the supervisors: What support do first-line supervisors need to be more effective in their supervisory role? Aotearoa New Zealand Social Work, 31(3), 46-57. Retrieved from https://anzswjournal.nz/anzsw/article/view/647/657

14. Proctor B. (2000). Group supervision: guide to creative practice. London: SAGE Publications.

15. Soika I. (2017). Evolution of Dialogue for Students' Career Guidance in Secondary Vocational Education. In V. Dislere (Ed.), The Proceedings of the International Scientific Conference Rural Environment. Education. Personality (REEP), 10. Jelgava: LLU, 481-488. Retrieved from https://llufb.llu.lv/conference/REEP/2017/Latvia-Univ-Agricult-REEP-2017_proceedings-481-488.pdf

16. Stankus-Viša I. (2017). Supervīzija mūsdienās, tās mērḳi un kvalitātes kritēriji [Supervision Today, Its Goals and Quality Criteria]. In K. Mārtinsone, S. Mihailova, Supervīzija: teorija, pètījumi, prakse. Rīga: RSU, 19-27. (in Latvian) 